\title{
Radon concentrations in abandoned mines, Cumbria, UK: safety implications for industrial archaeologists
}

\author{
G. Gillmore ${ }^{1}$, H. Alizadeh Gharib ${ }^{1}$, A. Denman ${ }^{2}$, P. Phillips ${ }^{2}$, and D. Bridge ${ }^{3}$ \\ ${ }^{1}$ Kingston University, Geography, Geology and the Environment, Kingston-upon-Thames, UK \\ ${ }^{2}$ University of Northampton, School of Science and Technology, St. Georges Avenue, NN2 6JD, Northampton, UK \\ ${ }^{3}$ Cumbrian Amenity Trust Mining History Society (CATMHS), 3 Brigham Hill Mansion, Brigham, Cockermouth, \\ Cumbria, CA13 OT1, UK
}

Received: 7 February 2011 - Revised: 14 March 2011 - Accepted: 15 March 2011 - Published: 11 May 2011

\begin{abstract}
This paper presents a number of surveys performed in a geographical area of the UK, part of which until recently was considered low radon risk. The Cumbrian region was identified by the Building Research Establishment (BRE) in its 1999 guide as an area without a significant radon problem in the built environment. The geology of the region, which includes the Northern Pennine Orefield is varied, but consists of granites, andesites, tuffs, carbonates, sandstones and shales. Mineralisation has taken place (mostly lead and copper ores) primarily along fault and fracture zones, one example being Copper Valley, northwest of Coniston village. This work quantifies the risk of exposure to radon in a number of abandoned mine environments. High radon levels, up to $28589 \mathrm{~Bq} \mathrm{~m}^{-3}$, have been measured in parts of one mine. This study demonstrates that industrial archaeologists (such as the Cumbrian Amenity Trust Mining History Society or CATMHS members) and explorers of abandoned mines can be at risk from radon exposure and it proposes a management scheme to allow industrial archaeologists to continue exploration whilst minimising the risk to health from radon.
\end{abstract}

\section{Radon and safety}

There is considerable evidence to show that excessive radon levels in some mines cause lung cancer in miners (BEIR, 1999), and that the increase in lung cancers follows a linear relation with the increasing radon level. The International Commission on Radiological Protection (ICRP) have concluded that excessive radon levels are a health hazard (ICRP,

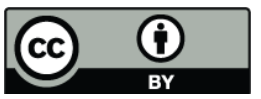

Correspondence to: G. Gillmore (g.gillmore@kingston.ac.uk)
1993) in homes and workplaces. In a recent study by Darby et al. (2005), it was shown that a modest risk from radon extends down to $100 \mathrm{~Bq} \mathrm{~m}^{-3}$ in domestic housing in line with the linear no-threshold theory.

In 1990, the UK National Radiological Protection Board (now the Health Protection Agency or HPA), proposed an Action Level of $200 \mathrm{~Bq} \mathrm{~m}^{-3}$ for domestic properties (Miles et al., 1992). An additional Target Level has recently been recommended (McColl et al., 2010) by the HPA of $100 \mathrm{~Bq} \mathrm{~m}^{-3}$ for domestic indoor radon in the UK following the World Health Organisation recommendations (WHO, 2009). Employers are also now required under the Ionising Radiation Regulations (IRR, 1999) to remediate if levels are above $400 \mathrm{~Bq} \mathrm{~m}^{-3}$, or the area must be declared a Controlled Area with limited access. For other ionising risks, in order to limit the risk of cancers, IR99 specify a $1 \mathrm{mSv}$ annual dose limit for members of the public, $6 \mathrm{mSvs}$ for radiation workers and $20 \mathrm{mSvs}$ for classified workers, who are required to have annual health checks. Calculating the radiation dose received from radon exposure can be useful when considering the risk to people occasionally exposed to radon and Denman et al. (1999) have shown that, in the built environment, fulltime workers exposed at $400 \mathrm{~Bq} \mathrm{~m}^{-3}$ receive radiation doses close to, but below, the $6 \mathrm{mSv}$ limit.

The HPA have demonstrated that several regions in the UK have elevated radon levels, a number being designated as "Affected Areas" (these are defined by greater than $1 \%$ of dwellings being above the Action Level; Miles et al., 1992). In Cumbria the Building Research Establishment (BRE, 1999) guide suggests that radon levels are such that generally no radon protection is required in new houses, although the guide does suggest that in the area of the mines a geological assessment should be undertaken prior to building. Additional measurements in houses and a detailed

Published by Copernicus Publications on behalf of the European Geosciences Union. 


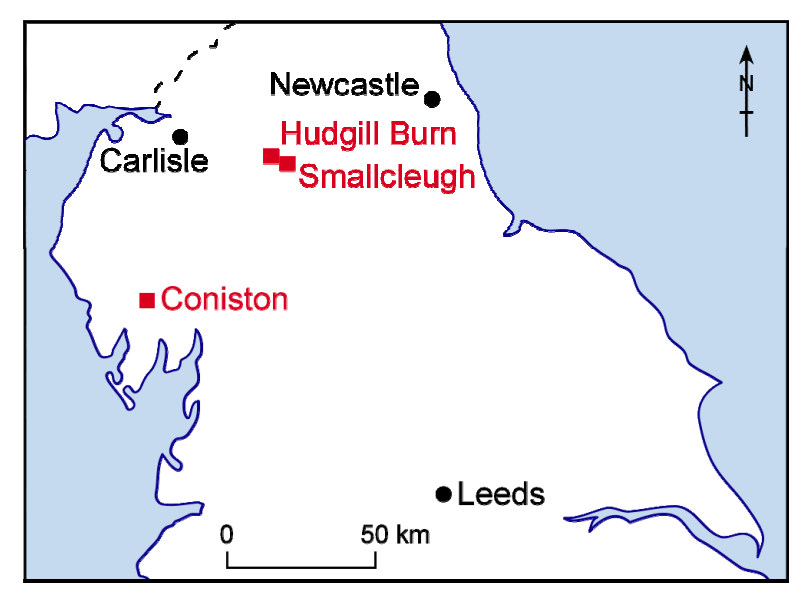

Fig. 1. Location map of Hudgill Burn, Smallcleugh and Coniston mines in Cumbria.

geological analysis by the British Geological Society has recently resulted in the publication of higher resolution maps (Miles et al., 2007) showing areas of high radon potential within the study area and revised BRE guidance for domestic housing (BRE, 2007). The 2007 maps indicate that in the village of Coniston, greater than $30 \%$ of the homes are above the Action Level, although the area of Coniston Copper Valley is identified as potentially having between $0-1 \%$ and 1-3\% of homes above the Action Level. This may be because there are very few homes close to the mines that the immediate area is shown as a relatively low radon area. The Smallcleugh and Hudgill Burn mines on the other hand occur in the Nenthead area in Cumbria and this region is identified as having between $5-10 \%$ and $10-30 \%$ of existing homes with radon levels above the Action Level in the 2007 map guide (Miles et al., 2007).

\section{Geology and mining history}

Hudgill Burn (Fig. 1) was a lead mine, which also contained silver deposits. The ore veins are unique in the Pennine Orefield not only for their structure, but also for the abundance of cerrusite (Dunham, 1990). The richest deposits were found in the thick grey-blue, fine-grained Great Limestone (Dunham, 1990). The mine was worked from 1814-1870, produced 54642 tons (approximately 55519 metric tonnes) of lead concentrates and from 1854-1870, $13 \mathrm{oz}$ (368.6 grams) of silver per ton (1.016 tonne) of lead (Dunham, 1990).

Smallcleugh Mine (Fig. 1) started around 1770 as a lead mine, with 4999 tons (5079 tonnes) of lead concentrates being extracted for the period 1848-1882. It contains ankerite, galena and sphalerite (zinc ore). There are also sulphate minerals in the form of epsomite (magnesium), melanterite (iron) and devilline (copper) together with annabergite (nickel; Dunham, 1990).

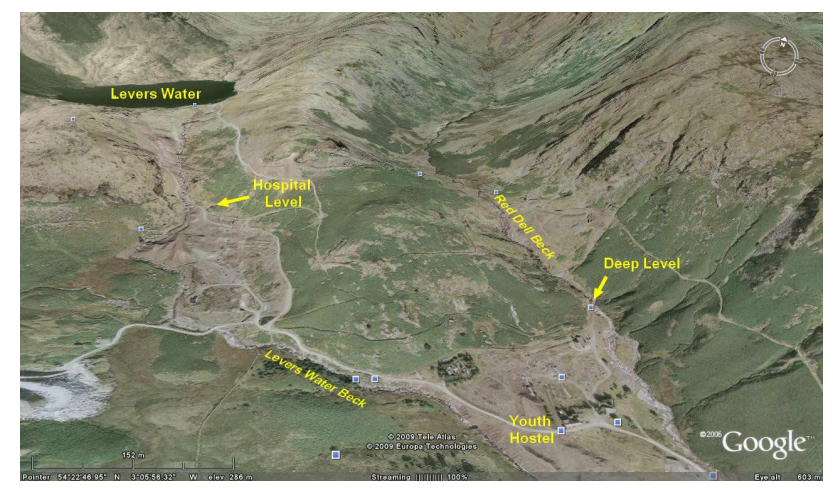

Fig. 2. Oblique aerial view of the Coniston Copper Valley and the mines visited during the 2008/09 survey. Arrows point out entrances to workings explored. Squares indicate mostly mine-related Google points of interest (ㄷ Google Earth 2009).

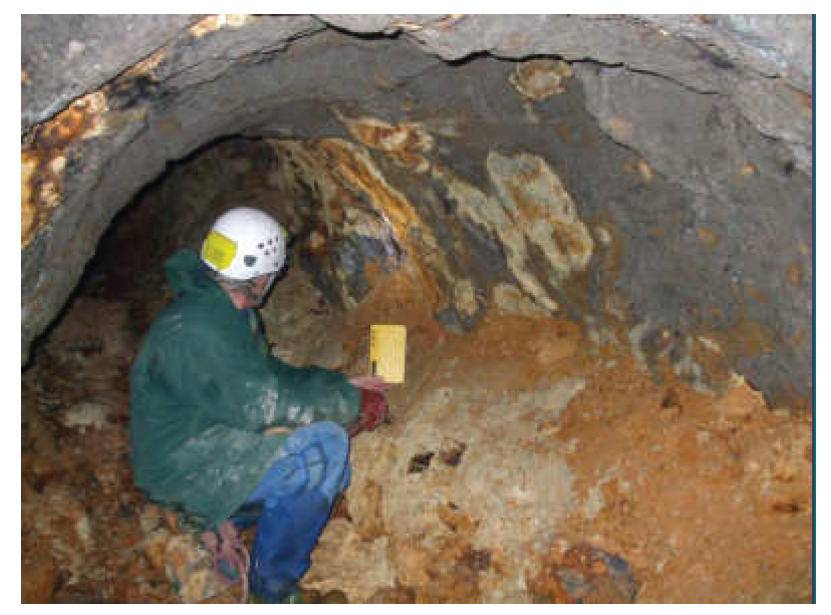

Fig. 3. Cross-cut to Brimfell, Paddy End mine, Coniston. The wall rock is crumbly, grey tuff and the ground is covered in ironstained mud and sand-sized weathered material. Notebook held by D. Bridge.

Coniston Copper mines (Figs. 1, 2, 3) lie in a region of hard volcanic rhyolite and andesitic lava interbedded with hardened and cleaved tuffs/ashes. Mitchell (1940) and Millward et al. (1999) have shown that the mineral veins that occur in faults and fissures are wide and productive within acid wall rocks, but are poor in andesite, andesitic tuff and volcaniclastic sandstone. South of Levers Water, these mineral veins trend southeast. From the early 17 th century Paddy End mine was exploited for copper (see Fig. 4), the primary ore being chalcopyrite. Other metallic minerals include magnetite, iron pyrites, arsenopyrite and nickel and cobalt (Holland, 1981). In the late 19th century, Coniston copper mines produced more than 50000 tons of dressed ore with 5-13 wt\% copper, along with 12 tons (12.19 tonnes) of lead and 3 tons (3.05 tonnes) of cobalt and nickel ore (Firman, 
1978). The mines in the valley visited in this study also included the Bonser (alternative spelling "Bonsor") Mine.

Since the 1950s, the copper mines of Coniston have been of historical interest and have continued to attract explorers, historians and tourists (Bridge, 2000). The abandoned Coniston mines are now undergoing a new phase of mineralization prompted by the empty space left behind after the cessation of mining activity. Colourful minerals such as erythrite, goethite, malachite, and limonite are gradually being deposited in and on walls, roofs and floors of adits and shafts.

Copper slag dumped from mining operations in the 19th century along Coniston water (e.g. at Moor Gill Foot, SD 297939) have been blamed for the pollution and the observed lower diversity in biota of the lake (Millward et al., 2000).

\section{Methods}

Radon levels were measured in August-September in 2000 and December 2000-January 2001 using commercial alpha track-etch CR39 detectors and at one mine in June 2008 and February-March 2009 using an in-house Radosys track-etch system, following the method laid out by Green et al. (1992) (Appendix A: Measurement methodology). Appropriate Quality Audit and Quality Control procedures were applied to both the laboratory and field procedures. The Kingston University laboratory is a Health Protection Agency, accredited radon testing facility and takes part in yearly European wide laboratory intercomparison studies. The Radosys system is also calibrated by the manufacturer for each new batch of track-etch detectors. The Radosys system was operated then, as described previously, by Gillmore and Jabarivasal (2010). Radon gas forms tracks in the CR39 plastic, with a linear response up to $5000 \mathrm{kBqh} \mathrm{m}^{-3}$. CR39 has a lower detection limit of around $50 \mathrm{kBq} \mathrm{h} \mathrm{m}^{-3}$. The exposure times were chosen to fit in this range, but accessibility issues resulted in some exposure times being close to the upper limit. For the later set of measurements, a manual counting check was also conducted to confirm the accuracy of the automatic system.

The detectors were left underground for between 6 and 35 days for the 2000/01 for up to 28 days for the 2008/09 season. Several volunteer industrial archaeologists wore CR-39 detectors on the outside of their clothing to assess personal exposure (referred to as personal detectors in this paper) for the duration of their mine visits.

During the installation at each mine locality, each detector was positioned at about $1 \mathrm{~m}$ above the ground. Every location in Coniston Copper Valley during the second visit was assigned a number and detectors were photographed in situ. Brief descriptions of the location and detector numbers were written in a field notebook and locations marked on the mine plan. In autumn and winter visits, air conditions (temperature and humidity) and the direction of air flow within the mine were recorded when possible.

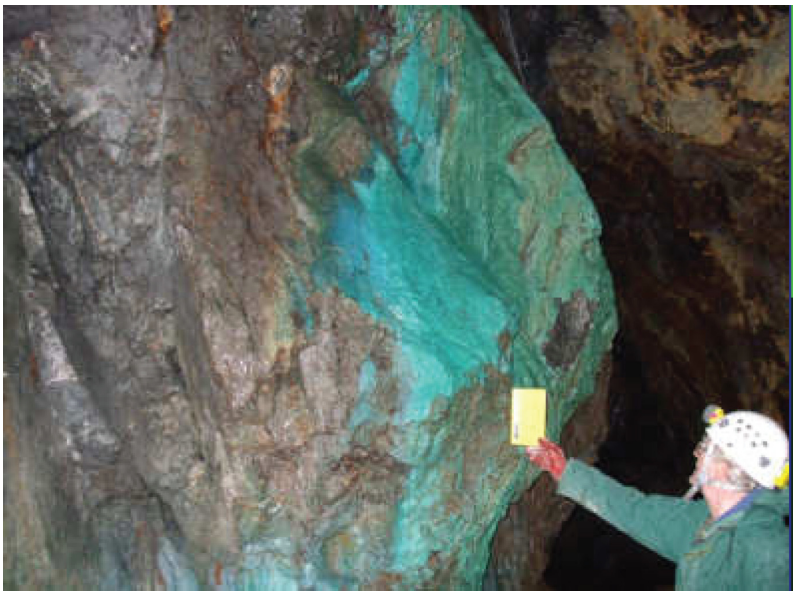

Fig. 4. Secondary copper mineralization near Paddy End Shaft. Field notebook held by D. Bridge.

\section{Results}

The radon levels from Hudgill Burn mine varied from $924 \mathrm{~Bq} \mathrm{~m}^{-3}$ to $28589 \mathrm{~Bq} \mathrm{~m}^{-3}$ (Table 1 ). The radon concentration at the active archaeological dig during winter $2000 / 01$ in this mine, which was at the 1st Sun vein, was $17183 \mathrm{~Bq} \mathrm{~m}^{-3}$. The third measurement period was somewhat disturbed by the national foot and mouth emergency in 2001 which meant that detectors had to be left in place for almost a year due to access difficulties over farmland. The results demonstrate a typical seasonal variation in caves with lower levels in winter than summer, the reverse of the situation in the built environment.

Radon levels in Smallcleugh mine, measured in the summer, were lower (Table 2), and varied from $805 \mathrm{~Bq} \mathrm{~m}^{-3}$ to $1695 \mathrm{~Bq} \mathrm{~m}^{-3}$. These levels were lower than the $27000 \mathrm{~Bq} \mathrm{~m}^{-3}$ suggested from a previous brief survey of north Pennine caves (D. Bridge, CATMHS, personal communication, 1998). There are several possible reasons for this - varying from measurements being taken at a different time or even position within the mine, to improved ventilation and flooding.

At Coniston Paddy End mine (Table 3, Fig. 5) radon levels varied from $80 \mathrm{~Bq} \mathrm{~m}^{-3}$ to $2152 \mathrm{~Bq} \mathrm{~m}^{-3}$ in $2000-01$. The latter mine was revisited in 2008/09 as part of an undergraduate dissertation project (Alizadeh Gharib, 2009; see Table 4). Many of the detectors on this second visit were placed in similar positions to the first set of detectors. Some were placed in a number of additional positions within the Copper Valley mines area, the highest reading being from one of the deepest parts into the mine. Higher radon concentrations were noted in the region of $4727 \mathrm{~Bq} \mathrm{~m}^{-3}$ in June 2008, whilst in the spring the high was $984 \mathrm{~Bq} \mathrm{~m}^{-3}$ and shows the same seasonal variation as the Hudgill Burn mine. 
Table 1. Radon concentrations measured in Hudgill Burn Mine.

\begin{tabular}{lrrr}
\hline & Radon (Bq m $\left.{ }^{-3}\right)$ & & \\
\hline Position & 6 to 12 Aug 2000 & $\begin{array}{r}\text { 16 Dec 00 } \\
\text { to 13 Jan 01 }\end{array}$ & $\begin{array}{r}17 \text { Feb 01 } \\
\text { to Jan 02 }\end{array}$ \\
\hline Blocked Level at Forehead. Just below Great Limestone & 28589 & & \\
Blocked Level at Forehead. Just below Great Limestone & 18478 & & \\
North Vein in blind heading in the tuft below Great Limestone & 17197 & 13391 & 2472 \\
450 m from entrance in the tuft below Great Limestone & 15975 & 8238 & 2469 \\
$10 \mathrm{~m}$ from entrance in shale & 9460 & 924 & 2245 \\
Dig on 1st Sun Vein & & 17183 & 2472 \\
Rise & & 2413 \\
\hline
\end{tabular}

Table 2. Radon concentrations measured in Smallcleugh mine.

\begin{tabular}{lccc}
\hline Position & Start & Finish & Radon $\left(\mathrm{Bq} \mathrm{m}^{-3}\right)$ \\
\hline 45 m from entrance in a flat & 12-Aug-00 & 16-Sep-00 & 805 \\
Elliot's string in blind heading - Limestone & 12-Aug-00 & 16-Sep-00 & 1337 \\
Gully back cross cut blocked level & 12-Aug-00 & $16-$ Sep-00 & 1028 \\
Gully back cross cut blocked level & 12-Aug-00 & $16-$ Sep-00 & 1695 \\
10 m from entrance & 12-Aug-00 & 16-Sep-00 & 203 \\
\hline
\end{tabular}

Table 3. Radon concentrations measured in Coniston Paddy End mine.

\begin{tabular}{lccc}
\hline Location & Start & Finish & Radon $\left(\mathrm{Bq} \mathrm{m}^{-3}\right)$ \\
\hline Top Level - Blind Spur & 13-Nov-00 & 24-Jan-01 & 289 \\
Top Level - Junction & 13-Nov-00 & 24-Jan-01 & 2152 \\
Arete Chamber & 13-Nov-00 & 24-Jan-01 & 97 \\
Top Level - Green Channel & 13-Nov-00 & 24-Jan-01 & 80 \\
Middle Level - Blue Rock & 13-Nov-00 & 24-Jan-01 & 592 \\
Grey Crag Level - Blind - 270 m from portal & 07-Jan-01 & 18-Jul-01 & 251 \\
Furthest Point Puddingstone Level & 07-Jan-01 & 18-Jul-01 & 826 \\
\hline
\end{tabular}

\section{Risk to industrial archaeologists}

Denman and Parkinson (1996) estimate the dose received from radon to occupants in the overground workplace, schools and domestic properties using the following formula, which was applied by Gillmore et al. (2001) to mines.

Dose (mSv)

$=\frac{\left(\text { Radon Concentration, } \mathrm{Bq} \mathrm{m}^{-3}\right) \times(\text { duration, hours })}{126000}$

The above equation assumes an Equilibrium Factor $(F)$ of 0.5 .

The risk is, therefore, dependent on the time spent in a mine and the radon level at that point. All three mines had some parts with radon levels over $400 \mathrm{~Bq} \mathrm{~m}^{-3}$, so that fulltime workers would receive a dose in excess of the legal limit if working in that part all year. For example, a worker spending $37.5 \mathrm{~h}$ a week working at the North Vein of Hudgill Burn Mine all year, where the annual average radon level was found to be $2472 \mathrm{~Bq} \mathrm{~m}^{-3}$, would receive a dose of $34.2 \mathrm{mSv}$. This assumes that this average is correct noting comments above regarding access difficulties for detector removal. On the other hand, an archaeological explorer making 4 visits to Elliot's string in the Smallcleugh mine in summer would receive $0.12 \mathrm{mSv}$, much lower than the dose limit. Archaeological teams work underground most Sundays when they are opening up a level, working for about $6 \mathrm{~h}$ over a period of weeks or months. Some keen explorers go underground regularly throughout the year and might spend several hours 
Table 4. Radon concentrations measured in Coniston Copper Valley, 2008/09. Detectors at sites 3 and 13 were not recovered. The Detector at site 3 because of a roof collapse.

\begin{tabular}{|c|c|c|c|c|c|}
\hline \multirow[t]{2}{*}{ Site No. } & \multirow{2}{*}{$\begin{array}{l}\text { Location } \\
\text { Measurement Period }\end{array}$} & \multicolumn{2}{|c|}{ Radon $\left(\mathrm{Bq} \mathrm{m}^{-3}\right)$} & \multicolumn{2}{|c|}{ Conditions } \\
\hline & & 2 to 29 Jun 2008 & 22 Feb to 22 Mar 2009 & 2 to 29 Jun 2008 & 22 Feb to 22 Mar 2009 \\
\hline 1 & $\begin{array}{l}\text { Junction of Bonser Vein } \\
\& \text { Deep Level Cross- } \\
\text { cut }\end{array}$ & 511 & 88 & No running water & $\begin{array}{l}\text { water dripping from } \\
\text { ceiling }\end{array}$ \\
\hline 2 & $\begin{array}{l}\text { Dead end, North } \\
\text { Cross-cut }\end{array}$ & 727 & 90 & Dry & \\
\hline 4 & $\begin{array}{l}\text { Small cavity near } \\
\text { junction of Deep Level } \\
\text { Cross-cut and Bonser } \\
\text { Vein }\end{array}$ & 517 & 82 & $\begin{array}{l}\text { near } 2-3 \mathrm{~cm} \text { running } \\
\text { water }\end{array}$ & \\
\hline 5 & $\begin{array}{l}25 \mathrm{~m} \text { inside Deep Level } \\
\text { Cross-cut, dry walls }\end{array}$ & 529 & 84 & $\begin{array}{l}\text { dry walls, } 2 \mathrm{~cm} \\
\text { running water }\end{array}$ & \\
\hline 6 & $\begin{array}{l}\text { Paddy End Mine, } 150 \\
\mathrm{~m} \text { in Cross-cut to Brim- } \\
\text { fell }\end{array}$ & 1322 & 758 & & \\
\hline 7 & $\begin{array}{l}\text { Spur, near collapsed } \\
\text { stope }\end{array}$ & 789 & 140 & Dry & \\
\hline 8 & $\begin{array}{l}8 \mathrm{~m} \text { long spur near } \\
\text { Gin Chamber in Bel- } \\
\text { man Hole Vein }\end{array}$ & 873 & 261 & & \\
\hline 9 & $\begin{array}{l}\text { Triddle Vein, dead end, } \\
\text { cleaved mineral vein }\end{array}$ & 3495 & 2173 & $1-2 \mathrm{~cm}$ water & $1-2 \mathrm{~cm}$ water \\
\hline 10 & $\begin{array}{l}\text { Junction of Cross-cut \& } \\
\text { North Cross-cut, pink } \\
\text { erythrite }\end{array}$ & 3998 & 2373 & $4-5 \mathrm{~cm}$ water & dry \\
\hline 11 & $\begin{array}{l}\text { Junction of } 2 \text { faults, } \\
\text { unstable wall rock }\end{array}$ & 4727 & & vapour in air & \\
\hline 12 & $\begin{array}{l}50 \mathrm{~m} \text { inside Hospital } \\
\text { Level }\end{array}$ & 663 & 91 & dry ground & \\
\hline 14 & $\begin{array}{l}\text { Taylor's Level, } 30 \mathrm{~m} \\
\text { inside adit }\end{array}$ & & 33 & & dry \\
\hline 15 & $\begin{array}{l}\text { Paddy End Mine, Bel- } \\
\text { man Hole Vein, spur to } \\
\text { left of adit, } 2 \mathrm{~cm} \text { water }\end{array}$ & & 984 & & $2 \mathrm{~cm}$ water \\
\hline 16 & Courtney's Cross-cut & & 96 & & $10 \mathrm{~cm}$ water \\
\hline 17 & $\begin{array}{l}\text { Kernal Vein, at adit en- } \\
\text { tranceway, adit heavily } \\
\text { faulted }\end{array}$ & & 145 & & $5 \mathrm{~cm}$ water \\
\hline 18 & $\begin{array}{l}90 \text { m inside Gaunt's } \\
\text { Level }\end{array}$ & & 144 & & $\begin{array}{l}20-25 \mathrm{~cm} \text { water near } \\
\text { entranceway, wet wall } \\
\text { rock }\end{array}$ \\
\hline
\end{tabular}




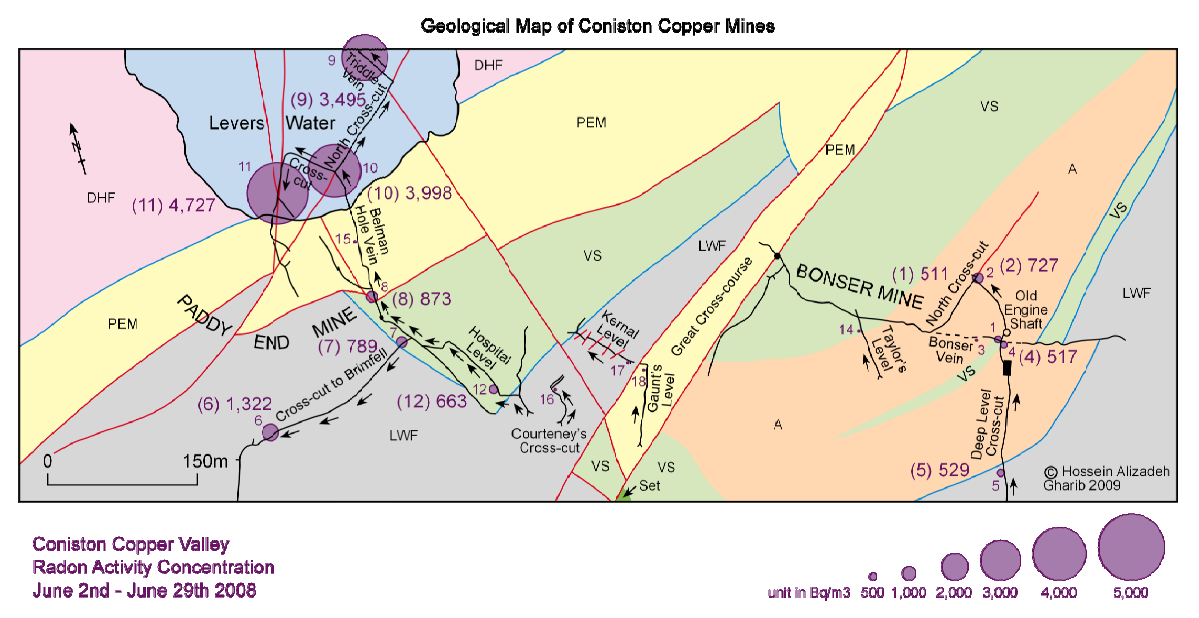

Fig. 5. Radon Activity Concentration map of the mines in Coniston Copper Valley, for 2 to 29 June 2008. Red-purple circles represent radon concentration in $\mathrm{Bq} \mathrm{m}^{-3}$. Black arrows are the direction of movement within the mine workings. DHF is the Duddon Hall Formation andesitic tuff; PEM is Paddy End Member rhyolitic tuff; LWF is Low Water Formation lapilli tuff and lapilli; VS is bedded tuff and volcaniclastic sandstone; A is andesite; and Set is Seathwaite Fell Formation volcaniclastic sandstone. Red lines are faults, black lines are mine adits covered in this survey.

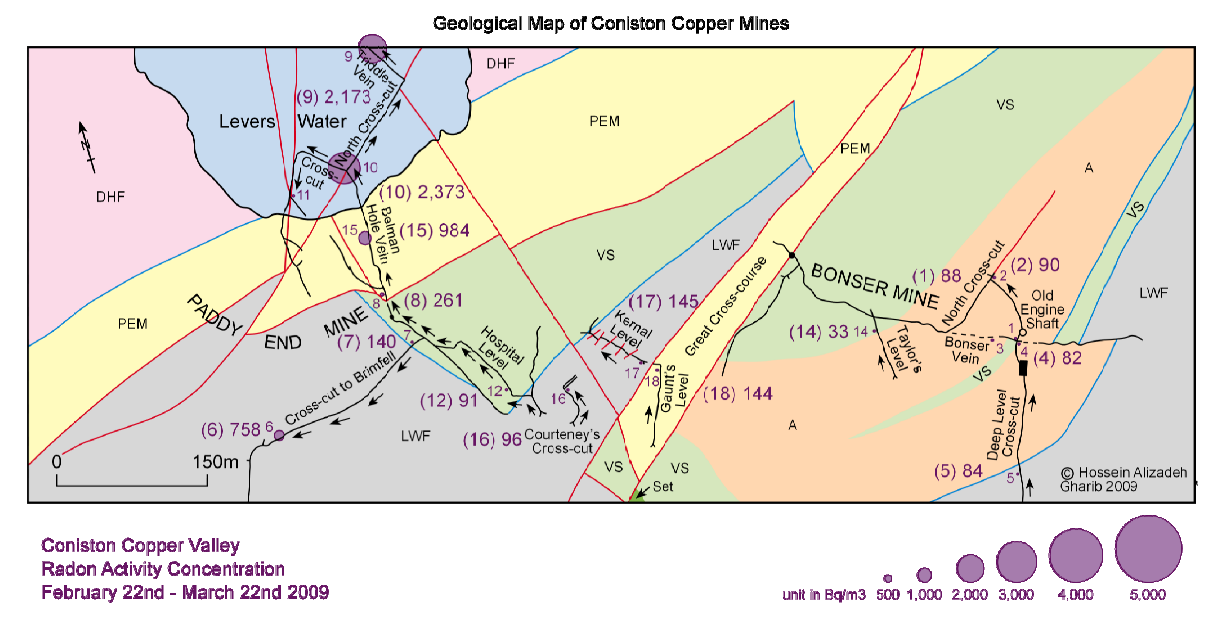

Fig. 6. Radon Activity Concentration map of the mines in Coniston Copper Valley, for 22 February to 22 March 2009 . Red-purple circles represent radon concentration in $\mathrm{Bq} \mathrm{m}^{-3}$. Black arrows are the direction of movement within the mine workings. DHF is the Duddon Hall Formation andesitic tuff; PEM is Paddy End Member rhyolitic tuff; LWF is Low Water Formation lapilli tuff and lapilli; VS is bedded tuff and volcaniclastic sandstone; A is andesite; and Set is Seathwaite Fell Formation volcaniclastic sandstone. Red lines are faults, black lines are mine adits covered in this survey.

a week at different mine sites. There is no particular preference for winter or summer working, although winter activities are dependent on weather conditions due to more limited mine access.

As can be seen, the dose received by visitors to mines can be limited by restricting the time spent in the mine. In addition, if there is a known radon risk, radon monitors can be worn by the individuals concerned. The simplest detector is the track etch detector, but this is only assessed retrospectively.
It should be noted that $F$ in mines varies widely (Gillmore et al., 2001). $F$ is likely to be the lowest at the entrance, where values down to 0.04 have been recorded, where the radon can diffuse into the atmosphere, and the highest is deep in the mine where there is little or no ventilation. In such circumstances, $F$ can reach 0.95 (Langridge et al., 2010). Whilst some studies assume $F$ of 0.2 (e.g. NPRB report M667), in our experience, 0.4 to 0.5 is not atypical of accessible cave and mine systems. 


\section{Action: advice to industrial archaeologists}

Show caves and mines are subject to the IRR (1999) and, hence, monitored and regulated by the Health and Safety Executive (HSE) or local authority Environmental Health Officers (EHO), to protect people working as guides. Owners of abandoned mines who allow visitors are also subject to the same regulations. As shown by this example, radon maps of radon levels in the built environment may not be an accurate guide to the risk from radon in underground works, and it would be an advisable safety check to place a radon monitor in any newly discovered old mine. Work by the authors (Gillmore et al., 2001) suggests that metallic ore mines appear to have raised risk of high atmospheric radon concentrations.

In 2000, Hudgill Burn mine was being actively opened up by CATMHS. In January 1998, CATMHS gained access to a large part of the old lead workings, as well as a $300 \mathrm{~m}$ long natural cavern. The society is still actively opening up the mine system. In the light of this, a study was undertaken on radon levels and the potential health effects and risks to volunteers.

There is considerable seasonal variation in the results for the entrance to Hudgill Burn mine (Table 1), but levels within the mine vary less. In many mines and caves, higher radon levels have been associated with wet weather and it may be that the December 2000 levels are higher than normal because of the higher than average rainfall. However, the seasonal variation found is within the range of seasonal variations noted in the literature (Gillmore et al., 2001).

These levels should be compared with the Action Level for workplaces of $400 \mathrm{~Bq} \mathrm{~m}^{-3}$ defined in the Ionising Radiations Regulations (1999). As the level within Hudgill Burn mine cannot be altered by forced ventilation, there is a legal onus on industrial archaeological organisations to ensure that doses received by volunteers are restricted to the legal limits. This can be done by limiting the time spent in such a mine as Hudgill Burn and monitoring the dose via personal radon detectors.

As shown above, once radon levels are known, it is possible to estimate the maximum time which it is safe to spend in different parts of the mine and consider whether the risk is sufficiently close to the limit to make it advisable to wear personal radon monitors.

Radon exposure is dominated by the exposure received deep in the mine at the dig face. Bearing in mind the values above, it was recommended to industrial archaeologists that the time spent at the dig face of an untested mine should be restricted to $4 \mathrm{~h}$ each month. This time restriction ensures that the annual dose would only approach $6 \mathrm{mSvs}$ if the person was exposed to an annual average radon level of $16000 \mathrm{~Bq} \mathrm{~m}^{-3}$ at the dig face. This recommendation would be valid for cave systems as well, as a comprehensive review by Field (2007) indicates that only a few cave systems exceed this value. It was also recommended that volunteers should wear personal radon dosimeters for a month at a time, so that the dose could be monitored throughout the year. It would seem prudent to extend this recommendation to any cave or mine in the UK as well as for the locations in this study.

\section{Conclusions}

This research is ongoing and work is under way to map more mines in the Lake District with the aid of CATMHS. The variation in radon levels between and within such abandoned mines needs to be adequately modelled if accurate exposure data is to be derived. Future work will also look in more detail at seasonal radon variability and meteorological conditions within the Lake District mines and other similar systems.

However, the research so far clearly shows that radon levels in abandoned mines are not closely correlated to radon levels in the nearby built environment, since mines with high radon levels have been found in areas designated as having low radon potential, and the potential for raised radon levels in any newly discovered mine needs to be considered as it has the potential of being a significant risk to groups such as Archaeologists spending time in the mines. This paper proposes a time limit of $4 \mathrm{~h}$ per month in any mine where radon levels are unknown, and an initial summertime assessment of radon levels using track etch detectors exposed over one to three months. Once this has been done, a more appropriate time restriction can be proposed and personal radon monitoring considered if radon levels are high.

Acknowledgements. The authors would like to thank Robin Crockett for comments made on this manuscript, and Sheila Barker of CATMHS for underground work at Hudgill Burn and Smallcleugh.

Edited by: F. Perrier

Reviewed by: two anonymous referees

\section{References}

Alizadeh Gharib, H.: Seasonality in radon levels of abandoned metalliferous mines, Coniston Copper Mines, Cumbria NW England and Great Orme Mines, Conwy, Wales. Unpublished BSc thesis, Kingston University, 2009.

BEIR VI: Committee on Health Risks of Exposure to Radon. Health effects of exposure to radon, Washington DC: National Academic Press, ISBN 0-309-05645-4, 1999.

Bridge, D.: A pictorial tour of the Coniston copper mines, Cumbria Amenity Trust Mining History Society, Cumbria, CD, 2000.

Building Research Establishment (BRE), Radon: guidance on protective measures for new dwellings, BR211, 1999.

Building Research Establishment (BRE), Radon: guidance on protective measures for new dwellings, BR211, 2007.

Darby, S., Hill, D., Auvinen, A., Barros Dios, J. M., Baysson, H., Bochicchio, F., Deo, H., Falk, R., Forastiere, F., Hakama, M., Heid, I., Kreienbrock, L., Kreuzer, M., Lagarde, F., Mäkelinen, I., Muirhead, C., Oberaigner, W., Pershagen, G., 
Ruano-Ravina, A., Ruosteenoja, E., Schaffrath Rosaria, A., Tirmarche, M., Tomáscaronek, L., Whitley, E., Wichmann, H. E., and Doll, R.: Radon in homes and risk of lung cancer: collaborative analysis of individual data from 13 European case-control studies, British Medical Journal, 330, 223229, doi:10.1136/bmj.38308.477650.63, 2005.

Denman, A. R., Barker, S. P., Parkinson, S., Marley, F., and Phillips, P. S.: Do the UK workplace Radon Action Levels reflect the Radiation Dose received by the Occupants?, Journal of Radiological Protection, 19(1), 37-43, 1999.

Denman, A. R. and Parkinson, S.: Estimates of radiation dose to National Health Service workers in Northamptonshire from raised radon levels. Short communication, The British Journal of Radiology, 69, 72-75 1996.

Dunham, K. C.: Geology of the Northern Pennine Orefield. Volume 1 Tyne to Stainmore, second edition, Her Majesties Stationary Office, London, 1990.

Field, M. S.: Risks to cavers and cave workers from exposures to low-level ionizing a radiation from $222 \mathrm{Rn}$ decay in caves, Journal of Cave and Karst Studies, 69(1), 207-228, 2007.

Firman, R. J.: Epigenetic mineralization, in: The Geology of the Lake District, edited by: Moseley, F., Occasional Publications of the Yorkshire Geological Society, 3, 226-241, 1978.

Gillmore, G. K. and Jabarivasal, N.: A reconnaissance study of radon concentrations in Hamadan city, Iran, Nat. Hazards Earth Syst. Sci., 10, 857-863, doi:10.5194/nhess-10-857-2010, 2010.

Gillmore, G. K., Phillips, P. S., Denman, A. R., Sperrin, M., and Pearce, G.: Radon levels in abandoned metalliferous mines, Devon, Southwest England, Ecotoxicology and Environmental Safety, 49, 281-292, 2001.

Green, B. M. R., Cliff, K. D., Miles, J. C. H., and Lomas, P. R.: Radon studies in UK homes, Radiation Protection Dosimetry, 45, 519-522, 1992.

Holland, E. G.: Coniston Copper Mines: A Field Guide, Cicerone Press, Cumbria, UK, 1981.
International Commission on Radiation Protection: Protection Against Radon-222 at Home and at Work. ICRP Publication 65 Annuals of the ICRP 23 (2), Pergamon Press, Oxford, 1993.

Ionising Radiations Regulations: Health and Safety Executive, Statutory Instrument 3232, HMSO, 1999.

Langridge, D., Stokes, R. P., and Jackson, C. P.: Monitoring of Radon Gas in Caves of the Yorkshire Dales, United Kingdom, Journal of Radiological Protection, 30, 543-556, doi.10.1088/0952-4746/30/3/009, 2010.

McColl, N. P., Miles, J. C. H., Green, B. M. R., Dixon, D. W., Fey, R., Meara, J. R., Harrison, J. D., and Cooper, J. R.: Limitation of Human Exposure to Radon: Advice from the Health Protection Agency, RCE-15, ISBN 978-0-85951-669-3, 2010.

Miles, J. C., Green, B. M., and Lomas, P.: Radon affected areas: Derbyshire, Northamptonshire and Somerset, Documents of the NRPB, 3, 19-28, 1992.

Miles, J. C. H., Appleton, J. D., Rees, D. M., Green, B. M. R., Adlam, K. A. M., and Myers, A. H.: Indicative Atlas of Radon in England and Wales, HPA-RPD-033. Chilton, Oxon, UK, 2007.

Millward, D., Beddoe-Stephens, B., and Young, B.: Pre-Acadian copper mineralization in the English Lake District, Geological Magazine, 136(2), 159-176, 1999.

Millward, D., Johnson, E. W., Beddoe-Stephens, B. W., Young, B. R., Kneller, B. C., Lee, M. K., Fortey, N. J., Allen, P. M., Branney, M. J., Kokelaar, B. P., McConnell, B. J., Merritt, J. W., Petterson, M. G., Scott, R. W., Soper, N. J., Stone, P., Molyneux, S. G., Rushton, A. W. A., Cooper, D. C., Hirons, S. R., Roberts, B., Rundle, C. C., and Marks, R. J.: Geology of the Ambleside District, Memoir for 1:50 000 Geological Sheet 38, England and Wales, British Geological Survey, London, 228, 2000.

Mitchell, G. H.: The Borrowdale Volcanic Series of Coniston, Lancashire, Quarterly Journal of the Geological Society, London, 96, 301-319, 1940.

WHO: WHO Handbook on Indoor Radon. A Public Health Perspective, edited by: Zeeb, H. and Shannoun, F., ISBN 978924154767 3, 2009. 